\title{
PELATIHAN PEMBUATAN ES KRIM BAYAM BAGI IBU-IBU DI KELURAHAN JATIPULO, PALMERAH, JAKARTA BARAT
}

\author{
Rianita Pramitasari', Dennys Kurniawan Lianto', Hugo Alexander1, \\ Rakhdiny Sustaningrum ${ }^{2}$, dan Syarief Darmono ${ }^{2}$ \\ ${ }^{1}$ Fakultas Teknobiologi, Universitas Katolik Indonesia Atma Jaya, Kampus 3-BSD, Jl. Raya \\ Cisauk-Lapan No. 10, Tangerang, Banten, 15345, Indonesia \\ ${ }^{2}$ Fakultas Ekonomi dan Bisnis, Universitas Katolik Indonesia Atma Jaya, Kampus Semanggi, Jl. \\ Jenderal Sudirman No. 51, Jakarta, 12930, Indonesia \\ Email: rianita.pramitasari@atmajaya.ac.id
}

\begin{abstract}
ABSTRAK
Mayoritas penduduk di Kelurahan Jatipulo, Palmerah, Jakarta Barat bekerja sebagai pekerja kasar dengan pendapatan di bawah upah minimum provinsi. Sementara itu, para ibu sebagian besar sebagai ibu rumah tangga yang tidak memiliki pendapatan. Tujuan dari pengabdian masyarakat ini ialah untuk melatih keterampilan dan menumbuhkan semangat wirausaha para ibu tersebut melalui pelatihan pengolahan bayam menjadi es krim. Pengolahan bayam menjadi es krim dilakukan untuk memperpanjang umur simpan bayam dan meningkatkan nilai jual. Metode yang digunakan dalam program pengabdian ini terdiri atas penyuluhan dan pelatihan, dengan kegiatan: (1) penyuluhan kandungan gizi bayam, manfaat bayam, dan teori tentang pengolahan es krim bayam (2) praktik pelatihan pembuatan es krim bayam, serta (3) monitoring dan evaluasi. Secara umum, kegiatan penyuluhan dan pelatihan telah berjalan lancar tanpa kendala apapun. Para peserta berperan aktif selama peyuluhan dan pelatihan, baik dalam tanya jawab maupun praktik. Faktor pendorong lancarnya kegiatan tersebut ialah keingintahuan para peserta untuk berinovasi mengolah bayam menjadi produk yang memiliki nilai lebih. Dari hasil monitoring didapatkan informasi bahwa peserta sudah beberapa kali membuat es krim bayam, baik untuk konsumsi sendiri maupun untuk digunakan sebagai menu konsumsi acara mingguan ibu-ibu di wilayah tersebut. Dapat disimpulkan bahwa program pengabdian telah mampu memberikan wawasan pengetahuan baru terkait bayam serta pengolahannya menjadi produk es krim yang memiliki nilai lebih. Diperlukan pendampingan secara intensif dan berkelanjutan bagi para ibu-ibu yang ingin menjadikan produk es krim bayam mereka sebagai salah satu produk untuk berwirausaha.
\end{abstract}

Kata kunci: Bayam, Es Krim, Pelatihan 


\begin{abstract}
The majority of the population in Jatipulo village, Palmerah, Wes Jakarta, work as laborers with incomes below the minimum wage of the city. Meanwhile, most of the women are housewives who have no income. The community service aimed to train their skill and foster an entrepreneurial spirit by processing spinach into ice cream. The ice cream processing aims to extend the shelf life of spinach and increase its selling value. The methods used in this empowering program were teaching and training, with the following activities: (1) teaching of spinach nutrient content, spinach benefits, and the theory of the processing of spinach ice cream, (2) the practice of making spinach ice cream production, and (3) monitoring and evaluation. In general, training activities have been running smoothly without any sign of constraints. Participants play an active role during the training in both the discussion and practice. The driving factor of the activity is the curiosity of the participants to innovate the processing of spinach into products that have more value. Based on the monitoring results, the participants had several times made spinach ice cream for their consumption. It can be concluded that the program has provided insight into new knowledge related to spinach and the processing of spinach into ice cream that has more value. Intensive and sustained mentoring is required for the women who want to make their spinach ice cream as one of the products for entrepreneurship.
\end{abstract}

Keywords: Ice Cream, Spinach, Training

\section{PENDAHULUAN}

Jatipulo merupakan salah satu kelurahan yang terletak di pinggiran rel kereta stasiun Tanah Abang dan bantaran kali. Kelurahan tersebut merupakan bagian dari wilayah kecamatan Palmerah, Jakarta Barat. Mayoritas penduduknya adalah suku asli Betawi dan pendatang dari wilayah pinggiran rel kereta api yang pernah terdampak penggusuran. Mereka bekerja sebagai buruh, supir angkot, ojek online, dan berjualan gorengan atau jajanan pasar dengan pendapatan di bawah upah minimum kota/ provinsi (Darmoyo et al., 2019).

Guna menggerakkan masyarakat Jatipulo untuk meningkatkan kesejahteraan hidupnya, Tim Pengabdian dari Universitas Katolik Indonesia Atma Jaya telah melakukan pelatihan mengenai penumbuhan kesadaran $\begin{array}{llrr}\text { untuk } & \text { berwirausaha } & \text { melalui } \\ \text { budidaya } & \text { sayur-sayuran } & \text { di } & \text { lahan } \\ \text { sempit } & \text { menggunakan } & \text { sistim } \\ \text { hidroponik } & \text { dan } & \text { aquaponik }\end{array}$ (Sustaningrum \& Pramitasari, 2020). Salah satu sayuran yang digunakan dalam pelatihan budidaya tersebut ialah bayam. Bayam merupakan jenis sayuran daun yang banyak dikonsumsi oleh masyarakat di Indonesia. Dalam $100 \mathrm{~g}$ bayam segar mengandung $16 \mathrm{Kal}$ energi total, 0,9 g protein, 0,4 $\mathrm{g}$ lemak, 2,9 $\mathrm{g}$ karbohidrat, 0,7 g serat, 1,3 g abu, 166 $\mathrm{mg}$ kalsium, $76 \mathrm{mg}$ fosfor, 3,5 mg besi, $16 \mathrm{mg}$ natrium, 456,4 mg kalium, 0,13 mg tembaga, 0,4 mg seng, 2,67 mcg beta karoten, 2,29 mcg total karoten, 0,04 mg vitamin B1, 0,1 mg vitamin B2, 0,1 mg niasin, dan $41 \mathrm{mg}$ vitamin C (Kemenkes RI, 2018). Selain itu, bayam juga diketahui memiliki senyawa bioaktif yang berfungsi 
sebagai antioksidan (Jha et al., 2011) dan antimikrob (Maiyo et al., 2010).

Meskipun bayam memiliki kandungan gizi yang cukup tinggi, umur simpan bayam tergolong pendek akibat tingginya kecepatan respirasi dan transpirasi setelah dipanen (Kakade et al., 2015) dan kemunduran oleh kontaminasi mikrob (Medina et al., 2012). (Garrido et al., 2015) melaporkan bahwa bayam dengan penanganan proses minimal hanya bertahan selama dua hari pada suhu $4^{\circ} \mathrm{C}$. Apabila di simpan di suhu ruang, umur simpannya dapat menjadi lebih pendek karena akan cepat layu dan kering. Harga bayam juga murah sehingga kurang memiliki nilai jual apabila hanya dijual dalam bentuk segar.

Untuk meningkatkan nilai jual bayam dan memperpanjang umur simpannya, diperlukan pengolahan bayam menjadi produk pangan. Telah dilakukan pengabdian masyarakat untuk mengolah bayam menjadi keripik (Nurbaeti et al., 2022), rempeyek (Andari et al., 2019), dan nugget (Nasyiithoh, 2018). Selain itu, bayam dapat diolah menjadi es krim. Es krim merupakan makanan semi padat yang dibuat dengan cara pembekuan tepung es krim atau campuran susu, lemak hewani atau lemak nabati, gula, dan dengan atau tanpa bahan makanan lain dan bahan makanan yang diizinkan (BSN, 1995). Es krim banyak disukai oleh semua kalangan masyarakat (Fatlahah, 2013). Pengolahan bayam menjadi es krim sudah dilakukan oleh beberapa tim pengabdian masyarakat dengan sasaran, tujuan pengabdian, dan formulasi es krim yang berbeda-beda (Antong \& Maharani, 2017) (Darwis \&
Hiola, 2013). Akan tetapi, dalam pengabdian tersebut belum diberikan materi penyuluhan tentang pengetahuan kandungan gizi dan manfaat bayam. Oleh sebab itu, penting untuk dilakukan supaya masyarakat tidak hanya bisa membuat es krim saja, namun memahami karakteristik dan manfaat bayam serta teknik dalam mengolahnya supaya kandungan gizinya tetap terjaga.

Target luaran yang dihasilkan dalam pengabdian ini ialah produk es krim bayam. Pengolahan produk pangan biasanya dilakukan oleh ibuibu. Oleh sebab itu, sasaran dalam kegiatan ini adalah para ibu yang mayoritas bekerja sebagai ibu rumah tangga. Melalui kegiatan ini, diharapkan dapat menarik minat para ibu untuk lebih produktif mengolah sayuran menjadi suatu produk yang selain dapat digunakan untuk meningkatkan asupan gizi keluarga juga membuka peluang dalam wirausaha makanan.

\section{METODE}

Program pengabdian masyarakat ini dilaksanakan di Balai RW 08, Jatipulo, Palmerah, Jakarta Barat. Kegiatan dilakukan pada hari Jumat, 24 Agustus 2019. Peserta pengabdian merupakan ibu-ibu RW 08 Kelurahan Jatipulo yang berjumlah 25 orang.

Metode kegiatan yang digunakan dalam program ini ialah penyuluhan dan pelatihan. Materi penyuluhan yang diberikan meliputi kandungan gizi bayam, manfaat mengonsumsi bayam, teori pengolahan bayam menjadi es krim 
untuk memberikan nilai lebih terhadap sayuran bayam, baik untuk dikonsumsi sendiri maupun dijadikan produk dalam berwirausaha. Setelah penyuluhan, peserta diberikan pelatihan pembuatan es krim bayam. Peserta melakukan praktik mengolah bayam menjadi es krim dengan pendampingan Tim Pengabdi yang terdiri atas dosen dan mahasiswa. Monitoring dan evaluasi dilakukan 1,5 bulan setelah pelaksanaan program.

\section{HASIL DAN PEMBAHASAN}

Penyuluhan tentang kandungan gizi bayam, manfaat mengonsumsi bayam, dan teori tentang pengolahan bayam menjadi es krim diikuti oleh peserta dengan antusias (Gambar 1). Jalannya penyuluhan dilakukan secara interaktif dengan diskusi dan tanya jawab. Setelah sesi penyuluhan, dilakukan praktik pembuatan es krim bayam oleh peserta dengan pendampingan dari Tim Pengabdi. Peserta yang merupakan ibu rumah tangga tampak cekatan dan antusias melakukan tahapan demi tahapan proses.

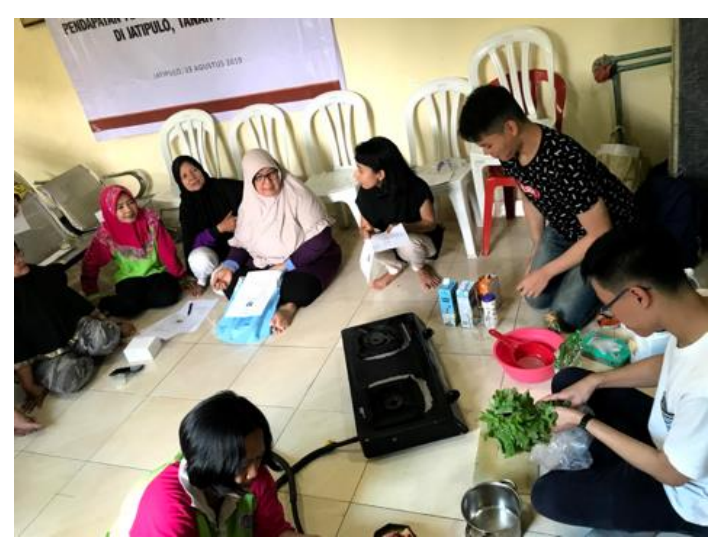

Gambar 1. Penyuluhan pembuatan es krim bayam
Tahapan proses pengolahan bayam menjadi es krim meliputi: perebusan bayam, penirisan bayam, pencampuran bayam dengan vanili, susu UHT, tepung maizena, krimer bubuk, gula pasir, whipping cream, dan kuning telur, perebusan dengan api kecil disertai pengadukan sampai mendidih, dan pembekuan selama semalam sampai menjadi es krim (Darwis \& Hiola, 2013) (Antong \& Maharani, 2017). Tim pengabdi sudah menyiapkan contoh es krim bayam yang dibuat dengan resep dan cara pengolahan yang sama untuk dicicip oleh peserta.

Di akhir sesi penyuluhan dan pelatihan, peserta ditanya secara lisan tentang kesan yang diperoleh dalam sebuah diskusi antara peserta dan tim pengabdi. Para peserta mengaku mendapatkan manfaat dari program ini. Adapun kesan peserta dari diskusi tersebut dirangkum dan disimpulkan dalam Tabel 1.

Tabel 1. Rangkuman kesan peserta terhadap materi kegiatan pengabdian

\begin{tabular}{cl} 
No & Kesan peserta \\
\hline 1 & Lebih paham tentang \\
& kandungan gizi dan manfaat \\
& mengonsumsi bayam. \\
2 & Tidak lagi menganggap remeh \\
& bayam sebagai bahan pangan \\
& murah. \\
& Mendapatkan wawasan baru \\
& tentang produk olahan bayam \\
& berupa es krim setelah \\
& sebelumnya hanya mengolah \\
& bayam menjadi sayur bening \\
& dan tumisan.
\end{tabular}

Penyuluhan dan praktik yang merupakan hal baru bagi para peserta tersebut cenderung untuk membuat 
peserta lebih antusias dalam mengikuti program (Nurbaeti et al., 2022). Secara umum, kegiatan penyuluhan dan pelatihan telah berjalan lancar tanda kendala apapun. Faktor pendorong lancarnya kegiatan tersebut ialah keingintahuan para peserta untuk berinovasi mengolah bayam menjadi produk yang memiliki nilai lebih. Mereka berharap dapat terus mencoba membuat es krim dari bayam.

Setelah jarak 1,5 bulan dari waktu pelaksanaan, dilakukan monitoring dan evaluasi terkait keberlanjutan program yang sudah diajarkan. Kegiatan monitoring dan evaluasi dilakukan pada tanggal 11 Oktober 2019 dengan melakukan kunjungan ke lokasi dan diskusi tentang penerapan kegiatan yang sudah dilakukan, bersamaan dengan program pengabdian lain yang dilaksanakan bersamaan dengan program ini (Sustaningrum \& Pramitasari, 2020). Dari hasil monitoring didapatkan informasi bahwa peserta sudah beberapa kali membuat es krim bayam, baik untuk konsumsi sendiri maupun untuk digunakan sebagai menu konsumsi acara mingguan ibu-ibu di wilayah tersebut. Akan tetapi, mereka belum mencoba membuat es krim untuk dijual. Para peserta menerapkan pembuatan es krim bayam dengan cara patungan untuk membeli bahan. Mereka juga sudah mencoba memodifikasi resep, salah satunya dengan mengganti susu UHT dengan santan. Dari hasil modifikasi resep, mereka menilai bahwa es krim bayam yang menggunakan susu UHT rasanya lebih enak dibandingkan dengan es krim yang menggunakan santan.

\section{KESIMPULAN}

Program penyuluhan tentang kandungan gizi dan manfaat mengonsumsi bayam serta pelatihan pembuatan es krim bayam telah dilaksanakan untuk membantu ibuibu RW 09 Jatipulo, Tanah Abang, Jakarta dalam memberikan wawasan pengetahuan baru terkait bayam serta mengolah bayam menjadi produk yang memiliki nilai lebih. Kegiatan telah berjalan lancar dengan dukungan partisipasi aktif para peserta. Berdasarkan monitoring dan evaluasi, produk es krim bayam telah berhasil dibuat secara mandiri oleh peserta. Meskipun demikian, diperlukan pendampingan secara intensif dan berkelanjutan bagi para ibu-ibu yang ingin menjadikan produk es krim bayam mereka sebagai salah satu produk untuk berwirausaha.

\section{UCAPAN TERIMA KASIH}

Penulis berterima kasih kepada Lembaga Penelitian dan Pengabdian Masyarakat (LPPM) Unika Atma Jaya atas dana yang diberikan untuk pelaksanaan program pengabdian melalui Hibah Pengabdian Lintas Unit tahun 2019.

\section{DAFTAR PUSTAKA}

Andari, A., Maulita, D., \& Hapsari, D. P. (2019). Peningkatan ekonomi masyarakat dengan berwirausaha rempeyek bayam di Desa Cigelam Kecamatan Ciruas Kabupaten Serang. Kaibon Abhinaya: Jurnal Pengabdian 
Masyarakat, $\quad 1(1), \quad 1$. https:// doi.org/10.30656/ka.v1i 1.985

Antong, A., \& Maharani, A. (2017). Pengolahan sayur bayam menjadi es krim di Kelurahan Purangi Kecamatan Sendana Kota Palopo. Equilibrium: Jurnal Ilmiah Ekonomi, Manajemen Dan Akuntansi, 6(1), 1-4. https:// doi.org/10.35906/je001.v $6 \mathrm{i} 1.163$

BSN. (1995). SNI 01-3713-1995 Es Krim. Badan Standardisasi Nasional, 8.

Darmoyo, S., Sustaningrum, D., \& Sanie-Herman, S. (2019). Pengembangan bisnis sosial dari pengelolaan limbah rumah tangga untuk pengentasan kemiskinan di Jati Pulo, Jakarta Barat. 2(2), 56-69.

Darwis, K., \& Hiola, S. K. (2013). Olahan sayuran menjadi es krim nabati pada ibu-ibu RT 03/04 di Kelurahan Tamalanrea Jaya. Journal of Chemical Information and Modeling, 53(9), 1689-1699.

Fatlahah, A. (2013). Pengaruh kualitas produk dan citra merek terhadap keputusan pembelian es krim Wall's Magnum. Ilmu Manajemen, 1(2), 472-485.

Garrido, Y., Tudela, J. A., \& Gil, M. I. (2015). Time of day for harvest and delay before processing affect the quality of minimally processed baby spinach. Postharvest Biology and Technology, 110, 9-17. https:// doi.org/10.1016/j.postha rvbio.2015.07.002

Jha, A., Upadhyay, A., Rasane, P., \&
Singh, H. (2011). No TitleQuantitative studies of phyto-chemicals of selected green leafy vegetables and their antioxidant potential. Medicinal Plants, 3(2), 1-5.

Kakade, A., More, P., Jadhav, S., \& Bhosle, V. (2015). Shelf life extension of fresh-cut spinach. International Journal of Agriculture, Environment and Biotechnology, 8(3),

609.

https://doi.org/10.5958/2230732x.2015.00067.4

Kemenkes RI. (2018). Data Komposisi Pangan Indonesia. www.panganku.org

Maiyo, Z. C., Ngure, R. M., Matasyoh, J. C., \& Chepkorir, R. (2010). Phytochemical constituents and antimicrobial activity of leaf extracts of three Amaranthus plant species. African Journal of Biotechnology, 9(21), 3178-3182. https://doi.org/10.4314/ajb.v9i2 1.

Medina, M. S., Tudela, J. A., Marín, A., Allende, A., \& Gil, M. I. (2012). Short postharvest storage under low relative humidity improves quality and shelf life of minimally processed baby spinach (Spinacia oleracea L.). Postharvest Biology and Technology, 67, 1-9. https://doi.org/10.1016/j.postha rvbio.2011.12.002

Nasyiithoh, H. K. (2018). Bola-bola singkong dan nugget bayam sebagai upaya peningkatan kreatifitas dan ekonomi ibu-ibu Dusun Bayeman, Sampung Ponorogo. Annual Conference On 
Community Engagement, 906-916.

Nurbaeti, Amelia, A. R., \&

Haeruddin. (2022). Edukasi

membudayakan masyarakat

mengkonsusmsi sayur bayam

melalui pengolahan kripik. 01(02),

35-41.

Sustaningrum, R., \& Pramitasari, R. (2020). Pemanfaatan lahan dan peningkatan pendapatan masyarakat dengan aquaponik di Jatipulo, Tanah Abang. Jurnal Kewirausahaan Dan Bisnis, 25(1), 1. https:// doi.org/10.20961/jkb.v2 $5 \mathrm{i} 1.41315$ 